\title{
FINACIAL REPORTING COMPLIANCE IN INDONESIAN LOCAL GOVERNMENTS: MIMETIC PRESSURE DOMINATES
}

\author{
Johan Arifin \\ Universitas Islam Indonesia \\ e-mail: arf.johan@gmail.com \\ Greg Tower \\ Curtin University \\ e-mail: Greg.Tower@cbs.curtin.edu.au \\ Stacey Porter \\ Curtin University \\ e-mail: Stacey.Porter@cbs.curtin.edu.au
}

\begin{abstract}
This study empirically examines the level of mandatory disclosure within financial statements of local governments in Indonesia by using institutional theory. Indonesia is the world's largest muslim country that has recently undergone comprehensive public sector reform. There is a moderate level of compliance with key mandatory disclosures (49.9\%). The highest level of communication is on issues relating to Fiscal Policy (81.2\%) whereas the lowest level is for Macro-Economic issues (33.6\%). Regression analysis shows that the mimetic isomorphism variable, measured by jurisdiction is positive and significant predictors of the extent of mandatory disclosure. Local governments that are located in Java disclose more than non-Java, and older local governments also have higher mandatory disclosures.
\end{abstract}

Keywords: Mandatory disclosure, financial statements, local governments. http://dx.doi.org/10.20885/jaai.vol19.iss1.art6

\begin{abstract}
Abstrak
Studi ini bertujuan untuk menguji tingkat pengungkapan wajib pada laporan keuangan pemerintah daerah di Indonesia dengan menggunakan perspektif teori institusional. Indonesia merupakan negara dengan komposisi penduduk muslim terbanyak di dunia yang barusaja melakukan reformasi sektor publik secara komprehensif. Hasil riset menunjukkan bahwa tingkat pengungkapan wajib dalam laporan keuangan sebesar 49,9\%, dimana pengungkapan tertinggi adalah pos kebijakan fiskal (81,2\%), sedangkan pengungkapan terendah adalah informasi mengenai ekonomi makro (33.6\%). Hasil analisis regresi menunjukkan bahwa variabel 'mimetic isomorphism' yang diukur dengan menggunakan proxi lokasi daerah (jurisdiksi) merupakan variabel prediktor yang secara positif signifikan mempengaruhi tingkat pengungkapan wajib. Selain itu, umur pemerintah daerah juga berpengaruh positif dan signifikan terhadap tingkat pengungkapan wajib pada laporan keuangan pemerintah daerah di Indonesia.
\end{abstract}

Kata kunci: Mandatory disclosure, financial statements, local governments

\section{INTRODUCTION}

Indonesia is a developing country in Asia that has recently undergone major state financial reform. The Government of Indonesia has implemented several of policies and regulations on local government financial management aimed 
at promoting improved systems and greater accountability over public resources managed by local governments. Of particular significance in the area of budgetary and financial management for local governments is the recent introduction of two regulations, Government Regulation No.24 of 2005 (PP No.24 of 2005), introducing new government accounting standards, and Minister of Internal Affair Decree No.13 of 2006 (Permendagri No.13 of 2006), bringing in new performance-based budgeting standards and guidelines for financial management of local government. Since 2010, the PP No.24 of 2005 was replaced by PP No.71 of 2010, which has implemented a full accrual accounting. These regulations play an increasingly prominent role in supporting government policy on decentralization in accordance with the Law (UU. No.32 of 2004).

Decentralization highlights the increasing need for accountability in local government (Mardiasmo 2002). In 2003, UU No.17 of 2004 was issued requiring government agencies including local government to provide an annual financial statement based on government accounting standards. Although the regulation has been in force for more than seven years, the Ministry of Finance has questioned the level of compliance (Mulyani 2010).

There is a clear need to research local government compliance, for example, the $\mathrm{Su}$ preme Audit Institution (Badan Pemeriksa Keuangan) in 2009 claims that the financial statements of local governments in Indonesia have not met the expected target. They state many Indonesian local governments have not fully prepared financial statement in accordance with standards and regulations. The Supreme Audit Board of the Republic of Indonesia is the highest (supreme) audit institution in the land is responsible for the auditing of the state finance, i.e. the budget implementations of the central government and local government, the stateowned enterprises, and those enterprises owned by the local governments in short, the entire wealth of the State. They have issued a series of reports with highlight problems with compliance in Indonesia local government.

Martani and Lestari (2010) argue that to obtain an unqualified opinion for Indonesian local government entities, there are four criteria that need to be considered including: compliance with accounting standards, the effectiveness of internal control, compliance with laws and regulations and the adequacy of disclosure (full disclosure).

Full disclosure in financial statements is very important to help avoid misconceptions in understanding financial statements (Marston and Shrives 1991). Studies on the level of mandatory or voluntary disclosure in the financial statements have been undertaken in various settings. Lennox (1999) reveals that audit quality affects the level of mandatory disclosure. According to Hackston and Milne (1996), industry type affects voluntary disclosures. In addition, Eng and Mak (2003) and Cheng and Courtenay (2006) argue that government ownership influences the voluntary disclosure of partiallyowned governmental bodies. These studies show that there are many factors that may affect the level of disclosure in the financial statements.

Copley (1991) investigates the influence of audit quality on the financial disclosure of local governments. The result provides evidence that there is positive relationship between audit quality and disclosure. Research in the private sector has found similar results where audit quality can induce the financial statement quality by improving the disclosure to reduce asymmetry information. Ingram and DeJong (1988) concludes that the coalition of voters, administrative powers, and management incentives significantly helps explain variations in the disclosure level on governmental financial statements. Robbins and Austin (1986) also note that administrative power and management incentives are associated with the disclosure quality. Cheng (1992) develops a political economic model based on the theoretical and empirical work in public choice and political science to 
help explain state government accounting disclosure choice. The model posits that state government accounting disclosure choice is influenced by its political environment and institutional forces.

This study examines key variables that are expected to influence the level of mandatory disclosure of financial statements in local governments in Indonesia. There are three important aspects to this study. First, this research uses institutional theory approach to examine the level of mandatory disclosure of financial statements and the informativeness of the statements of local governments in Indonesia.

Second, the research is conducted in Indonesia, a developing country that has recently undergone major state financial reform and has a unique governmental structure ${ }^{\mathbf{1}}$. Third, the findings of this study can be applied to develop and improve public sector governance appliations. In particular, these finding can serve as an input for public policy making in better calibrating the implementation of Governemnt Regulation (PP) No. 71 of 2010, to best obtain full implementation in all Indonesian government institutions by 2015 .

\section{LITERATURE REVIEW AND HYPOTHE- SIS DEVELOPMENT}

Studies on mandatory disclosure have adopted a variety of theories. These include agency theory (Mahoney 1995), legitimacy theory (Mobus 2005), capital market theory (Schon 2006), and institutional theory (Yoshikawa, Tsui and McGuire 2007). Among these theories, agency theory and institutional theory are the most widely used by mandatory disclosure researchers (Mucciarone 2008). Recently, some researchers have employed institutional theory in the public sector area specifically on mandatory disclosure (e.g. Buhr and Freedman 2001). Sejjaaka (2004) posits that this theory potentially provides greater insights of mandatory disclosure practices. Accordingly, this study adopts institutional theory as the underlying theoretical framework explaining mandatory disclosure practices in Indonesia.

Institutional theory explains that organizations are faced with institutional pressures and due to these pressures those organizations tend to become very similar in their form and practices (Perera 2007; Deegan 2006). Institutional theory is concerned with how organizations structure themselves to gain acceptance and legitimacy which may be at the expense of efficiency. Legitimacy is the acceptance of an organization by certain social actors in society as not all parties have the standing to confer legitimacy. Pressures to conform arise from a variety of factors including uncertainty and task requirements, professional norms and standards, and a broader normative environment (Dacin 1977).

Institutional theory has two main dimensions: isomorphism and decoupling (Deegan 2006). Isomorphism, as used in this study, refers to particular practices by an organization because of institutional pressures (DiMaggio and Powell 1983) while decoupling refers to a situation in which the apparent practice of an organization is different from the actual practice (Meyer and Rowan 1977). In the context of this study, it can be said that isomorphism is the process by which mandatory disclosure practice in a local government is influenced by institutional pressures. Whereas decoupling is a situation in which mandatory disclosure practice is used by an organization to create an image which is different from that organization's circumstances or activities. In accordance with the purpose of this research which relates to the factors that influence the level of mandatory disclosure in local governments, this study solely utilises the isomorphic institutional dimension as the underlying theoretical framework.

DiMaggio and Powell (1983, p.149) label the process by which organizations tend to adopt the same structures and practices as 'isomorphism', which they describe as a homogenization of organizations. Tolbert and Zucker (1983, p.17) state when describing municipality 
reform "...the rapid institutionalization of the reform rested on the assumed isomorphism between it and the ideal rational bureaucratic form". Several studies (Perrow 1985; Covaleski and Dirsmith 1988; and Tagesson 2008) are based on institutional isomorphism in accordance with the concepts put forward by DiMaggio and Powel (1983).

As proposed by institutional theorists, by becoming 'isomorphic', organizations may achieve legitimacy (DiMaggio and Powell 1983). Kostova and Zaheer (1999) note that institutional theory supporters such as DiMaggio and Powell (1983) and Meyer and Rowan (1977) have identified some of the determinants of organizational legitimacy and the characteristics of the legitimating process. They cite three sets of factors that shape organizational legitimacy: (1) the environment's institutional characteristics, (2) the organization's characteristics, and (3) the legitimating process by which the environment builds its perception of organizations. Furthermore, Kostova and Zaheer (1999, p.77) in their study on multinational enterprises, claim" given the multiplicity and variety of institutional environments and the cross country differences between these environments, achieving isomorphism becomes difficult". Carpenter and Ehsan (2001) and Ashworth, Boyne and Delbridge (2007) suggest that isomorphic pressures differ based on organizational characteristics. In a consistent theme, this study examines isomorphic variables such as size of local government, jurisdiction, and political influence, and their potential relationship with the level of mandatory disclosure.

Scott (1987) reviews four sociological formulations all claiming an institutional focus due to variations in definition on the concepts of institution and institutionalization. Scott (1987, p.499) describes institutionalization conceptions as "a process of instilling value; a process of creating reality; institutional systems as a class of elements and institutions as distinct societal spheres". This study considers several areas within institutional theory, including that de- scribing institutional systems as a class of elements. According to Scott (1987, p.497), "institutionalized belief systems constitute a distinctive class of elements that can account for the existence and/or elaboration of organizational structure". Furthermore, he states that:

Since the concept of institutionalization is not definitionally linked to a distinctive process that might cause an organization to change its structure in ways that make it conform to-become isomorphic with - an institutional pattern. The best known-classification is of this type is developed by DiMaggio and Powell (1983) who distinguished among coercive, mimetic and normative processes leading to conformity.

Joseph (2010) reveals that the most noticeable type of institutional force is coercive isomorphism. According to DiMaggio and Powell (1983, p.149), "coercive isomorphism results from both formal and informal pressures exerted by other organizations on which an organization may be dependent, as well as cultural expectation in which the organizations operate". The formal pressure they refer to is a regulative process where regulators have the capacity to set up rules and procedures, monitor compliance and, when necessary, apply sanctions.

DiMaggio and Powell (1983, p.150) then explain "mimetic isomorphism is where organizations tend to model themselves and imitate the practices and policies of those organizations perceived to be legitimate and successful". Mimetic isomorphism is often referred to as a response to uncertainty. Furthermore, Baker and Rennie (2006, p.88) states that "while these organizations may not be certain about what they should do when facing challenges by adopting structures and processes used by similar organizations, they are, at the very least being seen to be doing something".

Ryan and Purcell (2004, p.10) explain that "normative influences refer to shared norms of organizational members, that is, those values 
that may be unspoken, or expectations that have gained acceptance within organizations". The element of pressure is normally developed by professional and occupational groups (Rahaman et al. 2004). DiMaggio and Powell (1983) argue that the more highly professionalized a workforce becomes in terms of academic qualifications and participation in professional and trade associations, the greater the extent to which the organization becomes similar to other organizations in the fields. In addition, Baker and Rennie (2006, p.87) also cite another source of normative isomorphism, being expertise as a possible important resource in "the implementation of reform and help in identifying shortcomings in a practice". This study advances hypotheses using coercive, mimetic and normative isomorphic tenets.

\section{Coercive Isomorphism Related Hypothesis}

This study examines the independent variable size of local government within the framework of coercive isomorphism. Size of government organization has been examined previously in public sector accounting research as one of the stronger determinants of for example, choice of accounting standard or internet financial reporting. With regard to public sector accounting research, size of an organization has been found to have a positive relationship with the extent of disclosure in annual reports of state government (Taylor and Rosair 2000). Several studies use size of local parliament ${ }^{2}$ as a measurement of local government size (see Hix 2004). In line with coercive isomorphism of institutional theory, the local parliamentarians have the power to pressure local government executive to align with the society's aspirations. Accordingly this study uses the number of local representatives in Indonesian local parliament to measure size as a predictor of the level of mandatory disclosure in financial statements.

Indonesian local parliaments have a varying number of members, depending on the size and influence of the local government. As stated in Indonesian Act (UU No.10 of 2008), a member of local parliament is a political mediator of the people within a local government. The greater number of local parliament members, means the greater local community representatives who will hold a legislative function to influence local government executives in performing their duties (Sotiropoulos 2008). Therefore, there is potential greater pressure from those local members representing local community as a coercive influence of local government executives to make disclosures on their operational activities. To capture this potential coercive pressure the following hypothesis is proposed:

$\mathrm{H} 1$ : There is a positive association between number of local parliamentarians and the extent of mandatory disclosure in the local government financial statements.

\section{Mimetic Isomorphism Related Hypothesis}

Within the framework of mimetic isomorphism, a hypothesis is developed to test the impact of jurisdiction. State or local government's jurisdiction is arguably a mimetic pressure in relation to institutional theory. DiMaggio and Powel (1983) suggest that mimetic behavior occurs as a reaction to uncertainty. When organizations face situations where there is no clear cut course of action, they may limit the selection of structures or practices to those that are being used by other organizations that are viewed as being successful in the institutional environment. Furthermore, Palmer and Dunford (1993) state that organizations tend to model themselves after similar organizations in their field that are perceived to be more legitimate or successful. Thus, mimetic isomorphism is a response to organizational uncertainty in identifying the best course of action.

Jakarta is the capital of Indonesia and is located on the massively populated island of Java. The capital's Java location influences the surrounding area to get better life facilities. Potentially the amenities in every local government located in Java may be better than in non- 
Java. In addition, the government of Indonesia through the Ministry of Communications and Information (Kemkominfo) admit to having a gap in terms of construction and development of telecommunications facilities on the islands between Java and non-Java (Republika 2011). Ball (2001) and Leuz (2011) feel that the quality of telecommunication infrastructure will affect the quality of an entity's financial reporting. With a better communication system, an organization can more easily monitor its development, all matters relating to the operations can be shared to all stakeholders more quickly to support the advancement of the organization. In addition, Java has better educational facilities than nonJava. Most of leading universities are located in Java. Hoect (2006) argues that the quality of human resources will affect the quality of disclosures in the accountability report. Human resources have a dual role, as an object but also as subjects of development. As the object of development, human resource development is a goal to be sought after, and as the subject of human resource development actors act as the crucial progress. Moran et al. (2008) argues that human resource is an important factor related to the quality of accountability. An entity which has better human resource tends to have better financial accountability reports. In this regard, local governments which are located in Java potentially have better financial statements and disclosure practices than non-Java. Based on these ideas, the following hypothesis is proposed:

$\mathrm{H} 2$ : There is a positive association between local governments that are located on the island of Java and the extent of mandatory disclosure in the local government financial statements compared to non-Java entity.

\section{Normative Isomorphism Related Hypothesis}

Under normative isomorphism, a hypothesis is developed to test the impact of a possibly explanatory variable namely political influence. In the governance structure of public sector, local parliament is an institution that has an important check and balance function to ensure that the local government executives execute their job well in the interests of all stakeholders (Lyngstad 2010). Grigorescu (2008) interprets this function as horizontal accountability. This function can be used as an argument to support normative isomorphism pressure on local government executives to run the professional activities to meet the public interest. Ying and Zhengfei (2006) states that a decline in the quality of supervision of the executive would result in decreased quality of disclosure on the executive accountability report, including disclosures on its financial statements.

Silva (2009) argues that the composition of members of local parliament could be used as benchmarks to see the power of pressure exerted by the local parliament to the executive government. If the proportion of local parliament meber is dominated by the majority party, and the chairman of local government is from the same party or a coalition, then the quality of supervision conducted on the performance of the executive may decline. Based on these ideas, the following hypothesis is proposed:

H3: There is a positive association between the proportion of local parliament members who are independent of the executive and the extent of mandatory disclosure in the local government financial statements.

\section{RESEARCH METHOD}

From a total population of 496 local governments in Indonesia, stratified random sample $\mathrm{s}^{\mathbf{3}}$ of 80 financial statements are collected from the Supreme Audit Board of Indonesia (BPK) database for the period ending December 31, 2010. This data set is used to empirically test the three institutional theory hypotheses. The sample consists of 40 local governments in Java and 40 local governments outside Java. Both local governments' types are divided into district and municipality groupings. 


\section{Measurement Techniques}

\section{Dependent variable}

Informativeness of financial statements can be seen from the extent to which an entity provides an explanation (disclosure) on financial its financial statements (Ingram and DeJong 1988). In Indonesia, disclosure of local government statement is mandatory in accordance with the government regulation (PP No.24 of 2005) regarding Indonesian Government Accounting Standards. To examine the informativeness of financial statements in local governments in Indonesia, a Government Compliance Index (GCI) is created.

A disclosure index can be classified into weighted or unweighted index (see Cooke 1991). In a weighted disclosure index, particular disclosure items are given a higher score (when those items are disclosed) than the other disclosure items based on the perceived importance of those particular items (Cooke 1991). Whereas, in an unweighted index, each disclosure item is deemed equally important and therefore each item is awarded the same score when it is dis- closed (Meek, Roberts, and Gray 1995). Most prior studies use an unweighted disclosure index to measure the level of disclosure as this technique is considered far less subjective than a weighted index and is more relevant to all entities (Craig and Diga 1998). Accordingly, this study adopts an unweighted technique for scoring each disclosure item.

In a disclosure index, the contents of each annual report are compared to the items listed on a checklist and coded as 1 or 0 , depending upon whether or not the content conforms to the items listed on the checklist (Coy, Tower, and Dixon 1993). A disclosure index for every local government is then calculated as the ratio of total score awarded to the local government divided by the maximum number of items that are applicable for the entity. Such a measurement approach is suitable for measuring the level of disclosure in developing nations whose set of economic, politic and social conditions differ from those of developed nations (see Nurhayati, Brown, and Tower 2006).

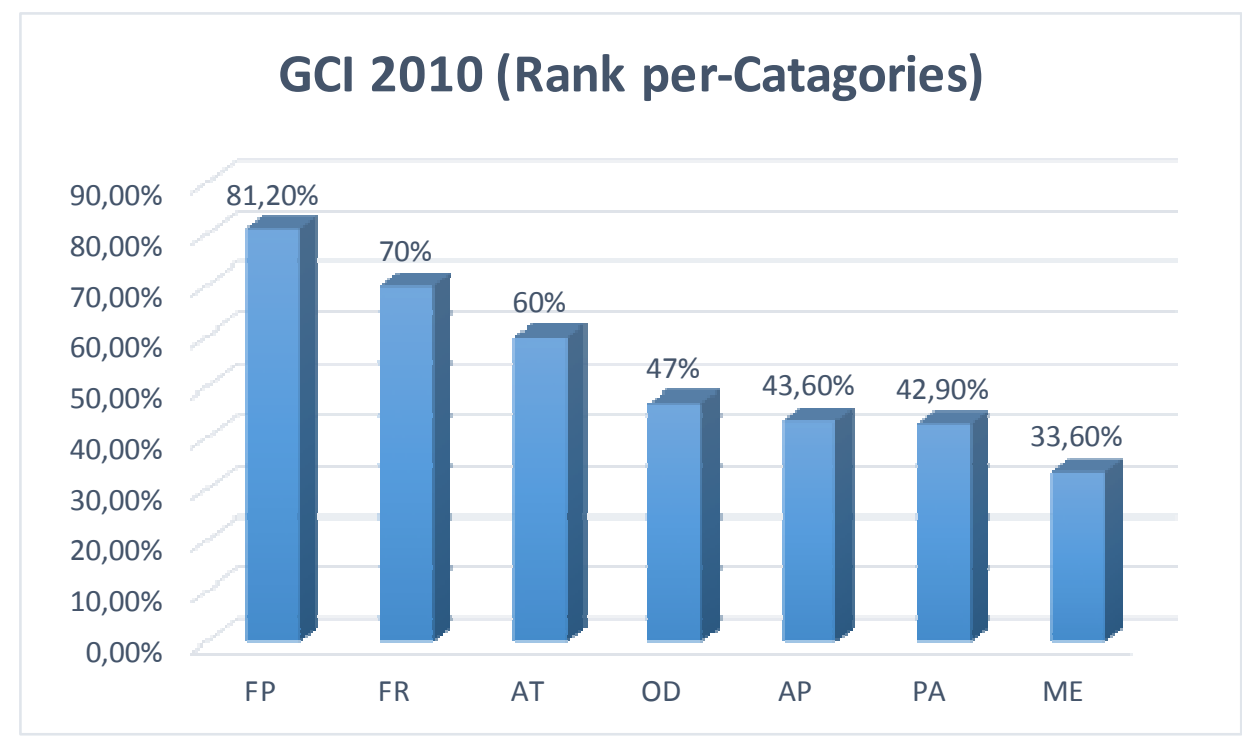

*The average overall GCI score is $49.9 \%$.

Legend: FP = information of Fiscal Policy; FR = Principals of Financial Reporting; AT = Information of Local Budget; OD = Other Disclosures; AP = Accounting Policy; $\mathrm{PA}=$ Performance Achievement; $\mathrm{ME}=$ Macro Economy

Figure 1: Government Compliance Index 2010 (by Categories) 
Figure 1 shows Government Compliance Index (GCI) categories. There are seven categories of GCI. Key explanatory factors highlighted from Figure 1 are:

- The average overall GCI score during 2009 is $49.9 \%$.

- There are seven categories of GCI in which Information on Fiscal Policy is the highest level of communication $(81.20 \%)$. This indicates that Indonesian local governments are very concerned about fiscal information which occurs in their area such as changes in financial position, revenue increases, expenditure efficiency, and others.

- The second most disclosed GCI category is Principles of the Financial Report (70\%). This indicates that the principles of financial statements are reasonable well communicated by Indonesian local government.

- The other categories are less well disclosed including Information of the Achievements of Local Budget Targets (60\%), followed by Oth- er Disclosure (47.0\%), Disclosure of Accounting Policy (43.6\%), and Presentation of Summary of Performance Achievement (42.9\%).

- Information of Macro Economics is the lowest category communication (33.6\%). This indicates that the information relating to macroeconomic issues got less attention by Indonesian local governments.

\section{Independent and Control Variables}

The measurement techniques for the independent and control variables are based on prior studies (Sotiropoulos, 2008; Hix, 2004; Huther and Shh , 1998; Sloan, 2011; Usman, 2001; Lev and Schwartz, 1971; Martani and Lestari, 2005; Stalebrink, 2007; Alicias et al., 2007). These are summarized in Table 1 . The possible influence of these variables on mandatory disclosures practices are tested by multiple regressions.

Table 1: Measurement Technique of the Independent and Control Variables

\begin{tabular}{|c|c|c|c|c|}
\hline & $\begin{array}{c}\text { Independent } \\
\text { Variables }\end{array}$ & $\begin{array}{c}\text { Control } \\
\text { Variables }\end{array}$ & Measurement & $\begin{array}{l}\text { Type of } \\
\text { Data }\end{array}$ \\
\hline $\begin{array}{l}\text { Coercive } \\
\text { isomorphism }\end{array}$ & $\begin{array}{l}\text { Size of local g®- } \\
\text { ernment }\end{array}$ & & $\begin{array}{l}\text { Total number of local government } \\
\text { parliamentrian s }\end{array}$ & Continuous \\
\hline $\begin{array}{l}\text { Mimetic } \\
\text { isomorphism }\end{array}$ & $\begin{array}{l}\text { Jurisdiction } \\
\text { (Java and non-Java) }\end{array}$ & & $\begin{array}{l}\text { It is measured by dichotomous cod- } \\
\text { ing: } \\
1=\text { if it is located in Java } \\
0=\text { if it is not located in Java }\end{array}$ & Categorical \\
\hline \multirow[t]{6}{*}{$\begin{array}{l}\text { Normative } \\
\text { isomorphism }\end{array}$} & Political Influence & & $\begin{array}{l}\text { Proportion of non controlling parties in } \\
\text { the local parliament }\end{array}$ & Continuous \\
\hline & & $\begin{array}{l}\text { Type of local govern- } \\
\text { ment }\end{array}$ & $\begin{array}{l}1=\text { Municipality } \\
0=\text { District }\end{array}$ & Categorical \\
\hline & & Age of entity & Number of years from inception & Continuous \\
\hline & & Audit Finding & $\begin{array}{l}\text { Number of audit finding recommenda- } \\
\text { tions }\end{array}$ & Continuous \\
\hline & & $\begin{array}{l}\text { Surplus/deficit of Local } \\
\text { Government }\end{array}$ & $\begin{array}{l}1=\text { if deficit (revenue }<\text { expenditure) } \\
0=\text { if surplus (revenue }>\text { expenditure) }\end{array}$ & Categorical \\
\hline & & Financial independence & $\begin{array}{l}\text { Ratio of Local Government Financial } \\
\text { Independence (RLGFI). }\end{array}$ & Continuous \\
\hline
\end{tabular}




\section{RESULTS AND DISCUSSION}

\section{Descriptive Results and GCI Analysis}

Results of descriptive statistics for the dependent, independent and control variables are summarized in Table 2. Table 2 shows that the mean of Government Compliance Index (GCI) level for the 80 strong samples of Indonesian local government is $49.9 \%$. This finding suggests that overall mandatory disclosure practices of Indonesian local governments are only moderately complied with the number of local parliament members in the 80 local governments' ranges from 20 to 50 people with the mean of 39 persons. This is in accordance with the regulation of Indonesian Electoral Commission No.17 of 2008 that the number of local parliament members shall be at least 20 seats and at most 50 seats. The proportion of minority par- ties in each local parliament is also quite varied with the lowest proportion being Cilegon (Javamunicipality) with $28.6 \%$, while the highest is Cimahi (Java-municipality) with $96.0 \%$. In addition, local governments in Indonesia have a very wide range of ages. The newest local government is Bengkulu Tengah (non-Java district), while Palembang (non-Java municipality) is the oldest as it has been in existence for 1327 years. The local government having the lowest audit finding is Sleman (Java district) with 8 findings, whereas the largest number of audit finding is Cianjur (Java-district) with 47 findings; the average is 23 . Finally, the minimum value of financial independence ${ }^{4}$ variable is $1.0 \%$ (Bengkulu Tengah, non-Java district), and the highest is $30.0 \%$ (Surabaya, Java municipality), with the average value is $9.6 \%$.

Table 2: Descriptive Statistics of the Dependent, Independent and Control Variables

Panel A: Continuous Variables

\begin{tabular}{lcccccc}
\hline \multicolumn{1}{c}{ Variable } & n & Min & Max & Median & Mean & Std Dev \\
\hline Government Compliance Index (\%) & 80 & 26.3 & 84.2 & 50.9 & 49.9 & 10.5 \\
Number ofParliament arians (\#) & 80 & 20 & 50 & 42 & 39 & 9.5 \\
Non-Supporting Parties (\%) & 80 & 28.6 & 96 & 66.7 & 67 & 13.8 \\
Age of Local Government (\#) & 80 & 3 & 1327 & 158 & 278 & 333 \\
Audit Finding (\#) & 80 & 8 & 47 & 22.5 & 23 & 7.6 \\
Financial Independence (\%) & 80 & 1 & 30 & 8 & 9.6 & 5.9 \\
\hline
\end{tabular}

Panel B: Categorical Variables

\begin{tabular}{lcc}
\hline Variable & Frequency & Percentage \\
\hline Java and Non Java & & 50 \\
Java & 40 & 50 \\
Non-Java & 40 & 50 \\
Type of Local Government & & 50 \\
Municipality & 40 & \\
District & 40 & 17.5 \\
Surplus/Deficit of LG & & 82.5 \\
Deficit & 14 & \\
Surplus & 66 & \\
\hline
\end{tabular}

Legend: Panel A shows the descriptive statistics of the dependent variable (GCI) and continuous independent variables. Panel B shows the descriptive statistics of categorical variables including independent and control variables. 
Table 3: Univariate Analysis Results of Independent Variables by Java-Non Java, DistrictMunicipality, and Surplus-Deficit

\begin{tabular}{lccc}
\hline \multicolumn{1}{c}{ Variable } & Java/Non-Java & District-Municipality & Surplus-Deficit \\
\hline Number of Parliamentarians & $.001^{*}$ & .428 & .579 \\
Non-Supporting Parties & .585 & .794 & .988 \\
Age of Local Government & $.021^{* *}$ & .288 & .524 \\
Audit Finding & $.003^{*}$ & .377 & $.012^{* *}$ \\
Financial Independence & $.001^{*}$ & $.000^{*}$ & $.023^{* *}$ \\
\hline
\end{tabular}

*highly significant at $1 \%$ level, **significant at $5 \%$ level, ***moderately significant at $10 \%$ level.

Table 3 shows significant differences for several predictor variables including Number of Parliamentarians, Non-Supporting Parties, Age of Local Government, Audit Finding, and Financial Independence between Java and Non-Java local governments, District-Municipality, and Surplus/Deficit of local governments. There are three variables that high significantly different between Java and Non-Java local governments such as Number of Parliamentarians ( $\mathrm{p}$-value = $0.001)$, Financial Independence ( $\mathrm{p}$-value $=$ 0.001 ) and Audit Finding (p-value $=0.003)$. In addition, Age of Local Government is significant at 0.05 level. There is only one variable that is not significantly different between Java and non-Java local governments, that variable is Non-Supporting Parties.
Furthermore, the variable of Financial Independence between Indonesian municipality and districts have highly statistically significant difference ( $p$-value $=0.000$ ). This indicates that this variable is likely strongly influenced by the geographic position of local governments and by type (municipality or district).

The table also highlights the results of univariate tests associated with all predictor variables on local government budget surpluses and deficits. The statistical analysis shows that audit finding and financial independence between budget surplus and deficit local governments have significant differences ( $\mathrm{p}$-value $=$ 0.012 and 0.023 ). These indicate that both variables are influenced by the condition of local government budget.

Table 4: ANOVA Analysis: By Category

\begin{tabular}{lccccc}
\hline \multicolumn{1}{c}{ Variable } & $\begin{array}{c}\text { Age } \\
(\#)\end{array}$ & $\begin{array}{c}\text { NumPar } \\
(\#)\end{array}$ & $\begin{array}{c}\text { Audfind } \\
(\#)\end{array}$ & $\begin{array}{c}\text { Indepcy } \\
(\#)\end{array}$ & $\begin{array}{c}\text { Nonsup } \\
(\boldsymbol{\%})\end{array}$ \\
\hline Java District & 368 & 46 & 20 & 8.9 & $\mathbf{6 7 . 5}$ \\
Non-Java District & 109 & 33 & 23 & 4.0 & $\mathbf{6 7 . 9}$ \\
Java Municipality & 359 & 36 & 20 & 14.8 & $\mathbf{6 8 . 8}$ \\
Non-Java Municipality & 277 & 38 & 27 & 10.8 & $\mathbf{6 5 . 0}$ \\
Average & 278 & 38 & 22 & 9.6 & $\mathbf{6 7 . 3}$ \\
Min & 3.0 & 20 & 8 & 1.0 & $\mathbf{2 8 . 6}$ \\
Max & 1327 & 50 & 47 & 30.0 & $\mathbf{9 6 . 0}$ \\
Sig & $\mathbf{. 0 4 7 * *}$ & $\mathbf{0 . 0 0 0 *}$ & $\mathbf{0 . 0 1 0 *}$ & $\mathbf{0 . 0 0 0 *}$ & $\mathbf{0 . 8 5 0}$ \\
F & 2.777 & 9.015 & 4.012 & 19.926 & $\mathbf{0 . 2 6 5}$ \\
\hline
\end{tabular}

*highly significant at $1 \%$ level, **significant at $5 \%$ level, ***moderately significant at $10 \%$ level.

Legend: Age=Age of local government; Numpar=Number of parliamentarians; Audfind=Audit finding; Indepcy=Financial Independence; Nonsup=Non-supporting parties 
Table 4 shows quite interesting information regarding the predictor variables associated with the condition of local government jurisdiction in Indonesia. Key variables have highly significant differences by the types of their jurisdiction, namely Java District, Non-Java District, Java Municipality, and Non-Java Municipality. These variables include the number of elected official in the local area (p-value $=0.000)$, financial independence of the local government ( $p$-value $=0.000)$ and number of critical audit finding ( $p$-value $=0.010)$. Moreover, it can be seen that age of local government also has significantly different ( $\mathrm{p}$-value $=0.047$ ). While only the non-supporting parties variable is not significantly different $(p$-value $=0.850)$.

\section{Regression Analysis}

To empirically test the three hypotheses, a series of backward regression are performed ${ }^{5}$. In such a regression, all predictor variables are entered into a model and sequentially removed until only significant variables remain with the maximum explanatory power (Cooper and Schindler 2006). Table 5 shows that the adjusted R-square value is explaining $20.9 \%$ of the variables. Ja$\mathrm{va} /$ non-Java (the mimetic construct) influences the Indonesia Government Compliance Index (GCI). This variable is highly statistically significant (p-value 0.004). Age of local government is also statistically significant ( $\mathrm{p}$-value $=$ 0.045 ). The coefficient of the two variables are positive, supporting the mimetic argument presented in prior section which posits that there are positive associations between mandatory disclosure practices and the jurisdiction as represented by the presence of Java/non-Java (Hypothesis 2) and age of local government (control variable). Other hypotheses variables (number of parliamentarians (Hypothesis 1) and non-supporting parties (Hypothesis 3)) and control variables (audit finding, financial independence, municipality-district, and surplus-deficit) are not statistically significant and therefore they are considered unable to explain the variation of mandatory disclosure practices in Indonesian local governments. The results generate evidence that local governments that are located in Java have higher mandatory disclosure practices than non-Java local governments. This implies that the more complete facilities and education located on the large and more prosperous island of Java can positively influence the level of mandatory disclosure practices. This finding therefore supports the statement of Hoecht (2006) that disclosure of financial statements will be better in jurisdictions with such positive characteristics, therefore local goverments with less facilities can mimic the communication of mandatory disclosure of local governments with more complete facilities.

\section{CONCLUSIONS}

The research presented in this paper focuses on an empirical analysis of the veracity of isomorphic institutional theory to predict the level of mandatory disclosure practices in Indonesia local governments. Indonesian government compliance index (GCI) checklist is created with key predictor variables (size of local parliament, Java/non-Java, and non-supporting parties) tested to explain the extent of such communication in 2010.

Table 5: Results of Backward Regression

\begin{tabular}{lccc}
\hline \multicolumn{1}{c}{ Vaiables } & Predicted Sign & Coefficient & $P$-Value \\
\hline (Constant) & & -.156 & .584 \\
Java and non-Java & + & .064 & $.004^{*}$ \\
Age of local Government (control variable) & + & .052 & $.045^{* *}$ \\
Adjusted $R^{2} .209$ & & & \\
F-Stat 11.443 & & & \\
Sig. .000 & & &
\end{tabular}

*highly significant at $1 \%$ level, $* *$ significant at $5 \%$ level, ***moderately significant at $10 \%$ level. 
In summary, from the three isomorphic components including coercive, mimetic and normative, only the mimetic component has a significant effect on the extent of mandatory disclosure (Java/non-Java). The mimetic variable provides evidence that mimic behavior leads to better quality human resources, location, and facilities for local governments in Indonesia. Local governments that are located in Java disclose more than non-Java. This finding supports the statement from Ball (2001) and Taylor (2010) that areas with good infrastructure and facilities have better financial statement and disclosure. Finally, age of local government is also influence on the extent of mandatory disclosure in Indonesian local governments. This finding supports Lev and Schwartz (1971) statement that the older the age of the entity likelihood of better quality because there has already been a long learning process. In contrast coercive and normative factors do not influence Indonesian local government reporting compliance levels.

A key finding in this research is that the Indonesian overall level of communication as measured by the GCI score is $49.9 \%$. There is a clear opportunity for improving the level of transparency. Several items are communicated very well by Indonesian local governments (above $80 \%$ even up to $100 \%$ ). While numerous other items are opaque (below 20\% and one of them has never been communicated at all by local governments). This variance indicates that there is a room for improvement. Indonesian governmental entities should put more energy into increasing their financial statement transparency. Transparency can be improved when there are clarity of tasks and authority, availability of information to public, open budgeting process, and guarantees of integrity regarding fiscal forecasts, information, with sufficient related detail (Campo and Tomasi 1999).

\section{REFERENCES}

Alicias, D., M. Djadijono, and T.A. Legowo.
2007. Decentralization Interrupted: Studies from Cambodia, Indonesia, Philippines and Thailand, Institute for Popular Democracy for Learning Initiative on Citizen Participation and Local Governance, Quezon City, Philippines.

Ashworth, R., G. Boyne, and R. Delbridge. 2007. Escape from the iron cage? Organizational change and isomorphic pressures in the public sector. Journal of Public Administration Research and Theory 19 (1): 165-187.

Austin, K.R., and W.A. Robbins. 1986. Disclosure quality in governmental financial reports: An assessment of the appropriateness of a compound measure. Journal of Accounting Research 24 (2): 412-421.

JSTOR. http://www.jstor.org/stable/2491145?ori gin $=$ JSTOR-pdf (accessed May 26, 2014).

Baker, R., and M. D. Rennie. 2006. Forces leading to the adoption of accrual accounting by the Canadian Federal Government: An institutional perspective. Canadian Accounting Perspectives 5 (1): 83-112.

Ball, R. 2001. Infrastructure requirements for an economically efficient system of public financial reporting and disclosure. Brookings-Wharton Papers on Financial Services. 127-169.

Biro Pusat Statistik (BPS). 2010. Kompas, April 29. p. 3.

Buhr, N. and M. Freedman. 2001. Culture, institutional factors and differences in environmental disclosure between Canada and United States. Critical Perspectives on Accounting 12 (1): 293-322. IDEAL.http://www.idealibrary.com.

Campo, S., and D. Tomasi. 1999, Managing Government Expenditure, Asia Development Bank, Manila. 
Carpenter L., and F. Ehsan. 2001. Institutional theory and accounting Rule choice: an analysis of four US state government' decisions to adopt generally accepted accounting principles. Accounting Organizations and Society 26 (1): 565-596.

Cheng, R.H. 1992. An Empirical analysis of theories on factors influencing state government accounting disclosure. Journal of Accounting and Public Policy 11 (1): $1-42$.

Cheng, E.C.M., and S. M. Courtenay. 2006. Board composition, regulatory regime and voluntary disclosure, The International Journal of Accounting 41 (3): 262-289.

Cook D., and D.M. Hawkins. 1990. Unmasking multivariate outliers and leverage points. Journal of the American Statistical Association 85 (411): 640-644.

Cooke, T.E. 1991. An assessment of voluntary disclosure in annual reports of Japanese corporations. The International Journal of Accounting 26 (3): 147-189.

Cooper, D.R., and P.S. Schindler. 2006. Business Research Methods. 9 ed. New York: McGraw-Hill.

Copley, P. A. 1991. The association between municipality disclosure practices and audit quality. Journal of Accounting and Public Policy. 10 (4): 245-266.

Covaleski, M.A., and M.W. Dirsmith. 1988. An institutional perspective on the rise, social transformation, and fall of a university budget category. Administrative Science Quarterly 33 (4): 562-587.

Coy, D., G. Tower, and K. Dixon. 1993. Quantifying the quality of tertiary education of annual report. Accounting and Finance. 33 (2): 121-129.

Craig, R., and J. Diga. 1998. Corporate accounting disclosure in ASEAN. Journal of In- ternational Financial Management and Accounting 9 (3): 246-274.

Dacin, M.T. 1977. Isomorphism in context: The power and prescription of institutional norms. Academy of Management Journal 40 (1): 46-81.

Deegan, C. 2006. Financial Accounting Theory, 2nd ed, Sydney: McGraw-Hill.

DiMaggio, P. J., and W.W. Powell. 1983. The iron cage revisited: Institutional isomorphism and collective rationality in organizational fields. American Sociological $48 \quad$ (2): 146-160. JSTOR. http://www.jstor.org (accessed April 11, 2014).

Eng, L.L., and Y.T. Mak. 2003. Corporate governance and voluntary disclosure. Journal of Accounting and Public Policy 22 (4): 325-345. Science Direct. http://www.sciencedirect.com(accessed May 10, 2014).

Grigorescu, A. 2008.Horizontal accountability in intergovernmental organizations. Ethics in International Affairs 22 (3): 285308.

Hackston, D., and M. J. Milne. 1996. Some determinant of social and environmental disclosure in New Zealand companies. Accounting, Auditing and Accountability Journal 9 (1): 77-108.

Hair, J.F., R.E. Anderson, R.L. Tatham, and W.C. Black. 1998. Multivariate data analysis. 5 ed. New Jersey: PranticeHall.

Hix, S. 2004. Electoral institutions and legislative behavior: Explaining voting defection in the European Parliament World Politics, World Politics 56 (2): 194-223. JSTOR. http://www.jstor.org/stable/25054255?or igin=JSTOR-pdf (accessed May 25, 2015). 
Hoecht, A. 2006. Quality assurance in UK higher education: Issues of trust, control, professional autonomy and accountabilty. Higher Education 51 (2): 541-563.

Huther, J., and A. Shah. 1988. Applying a simple measure of good governance to the debate on fiscal decentralization. Paper was presented at USAID Seminar on Democracy and Governance, ECLAC Seminar on Decentralization, Venezuela.

Ingram, R.W., and D.V. DeJong. 1988. The effect of regulation on local government disclosure practices. Journal of Accounting and Public Policy 6 (4): 245-270.

Joseph, C. 2010. Sustainability reporting on Malaysian local authority websites, Unpublished Doctoral Study. Curtin University. Perth Australia.

Komite Standar Akuntansi Pemerintahan. 2005. Peraturan Pemerintah Nomor 24 Tahun 2005 tentang StandarAkuntansi Pemerintahan. Jakarta: Salemba Empat.

Kostova, T., and S. Zaheer. 1999. Organizatioal legitimacy under conditions of complexity: The case of multinational enterprise. The Academy of Management Journal 24 (1): 64-81.

Lennox. C.S. 1999. Non-audit fees, disclosure and audit quality. European Accounting Review 8 (2): 239-252.

Leuz, C. (2011). Different approaches to corporate reporting regulation: How jurisdictions different and why. Accounting and Business Research. 40 (3): 229-256.

Lev, B., and A. Schwartz. 1971. On the use of economic concept of human capital in financial statements. The Accounting Review 46 (1): 103-112. JSTOR. http://www.jstor.org /stable/243891 (accessed May 26, 2014).
Lyngstad, R., 2010. Reconsidering Rationales for Local Self-Government Impacts of Contemporary Changes in Local Decision Making. Journal of Local SelfGovernment 8 (1): 93-113.

Mahoney, P. G. 1995. Mandatory disclosure as a solution to agency problems. The University of Chicago Law Review 62 (3): 1047-1112.

Mardiasmo. 2002. Elaborasi reformasi akuntansi sektor publik: telaah kritis terhadap upaya aktualisasi kebutuhan sistem akuntansi keuangan pemerintah daerah. Jurnal Akuntansi dan Auditing Indonesia 6 (1): 63-82.

Marston, C. L and P. J. Shrives. 1991. The use of disclosure indices in accounting research: A review article. The British Accounting Review 23 (3): 195-210.

Martani, D., and A. Lestari. 2010. Local government financial statement disclosure in Indonesia. University of Indonesia. Annual Meeting and Conference Asian Academic Accounting Association (AAAA), Bangkok, Thailand.

Meek, G.K., C. B. Roberts, and S. J. Gray. 1995. Factors influencing voluntary annual report disclosures by US, UK and continental European multinational corporations. Journal of International Business Studies 26 (3): 555-572.

Meyer, J. W., and B. Rowan. 1977. Institutionalized organizations: Formal structures as myth and ceremony. American Journal of Sociology 83 (2): 310-363.

Mobus, J. L. 2005. Mandatory environmental disclosures in a legitimacy theory context. Accounting, Auditing \& Accountability Journal 18 (4): 492-517.

Moran, D. D., M. Wackernagel, J. A. Kitzes, S. H. Goldfinger, and A. Boutaud. 2008. Measuring sustainable development - 
Nation by nation. Ecological Economics 64 (3): 470-474.

Mucciarone, M. A. 2008. Accountability and performance measurement in Australian and Malaysian government department. Unpublished Doctoral Thesis. Curtin University. Perth Australia.

Mulyani, S. 2010. Kualitas laporan keuangan pemerintah daerah Indonesia memburuk, Kompas, January 15.p.2.

Nurhayati, R., A. M. Brown, and G. Tower. 2006. Understanding the level of natural environmental disclosures by Indonesian listed companies. Journal of the Asia Pacific Centre for Environmental Accountability 12 (3): 4-11.

Palmer, I. and R. Dunford. 1993. Conflicting uses of metaphor: Reconceptualizing their uses in the field of organizational change. Academy of Management Review 21 (3): 691-712.

Peraturan Menteri Dalam Negeri No. 13 tahun 2006, Pedoman Pengelolaan Keuangan Daerah, Retrieved: 1 Juni 2011, from http://hukum.unsrat.ac.id/men/ permendagri_13_2006.pdf.

Perera, H. 2007. The international and cultural aspects of social accounting. In social accounting, mega accounting, and beyond: A festschrift in honor of M.R. Mathews, ed. R. Gray and J. Guthrie, 9199, St. Andrews: CSEAR Publishing.

Perrow, C. 1985. Review Essay: overboard with myth and symbols. American Journal of Sociology. 91 (1): 151-155.

Rahaman, A., Shiraz, S. Lawrence and J. Roper. 2004. Social and environmental reporting at the VRA: Institutionalized or legitimating crisis? Critical Perspectives on Accounting 15 (1): 35-56.

Republik Indonesia. 2003. The Act. No 17, 2003.

From http://www.dmo.or.id./dmodata 14Peraturan_dan_Ketentuan/1Undang_u ndang/UU_17_2003_ Keuangan Negara.pdf.

Robbins. W. A., and K. R. Austin. (1986). Disclosure quality in governmental financial reports: An assessment of the appropriateness of a compound measure. Journal of Accounting Research 24 (2): 412-421.

Ryan, C., and B. Purcell. 2004. Corporate governance disclosures by Local Government Authorities. Working paper, Queensland University of Technology, Brisbane, Australia.

Schon, W. 2006.Corporate disclosure in a competitive environment-the quest for a $\mathrm{Eu}-$ ropean framework on mandatory disclosure. Journal of Corporate Law Studies 6 (2): 259-298.

Scott, W. R. 1987. The adolescence of institutional theory. Administrative Science Quarterly 32 (4): 493-511. JSTOR.http://www.JSTOR.org/stable/23 92880 (accessed May 9, 2014).

Sejjaaka, S. 2004. A process based model for corporate mandatory disclosure. Accessed May 17, http://cpa.ug/A\%20Process\%20Based\% 20Model\%20of\%20Corporate\%20Mand atory\%20Disclosure.pdf.

Silva, C. N. 2009. Local political leadership in Portugal: Excepcionalism or convergence towards a 'Mayoral Model'?.Journal of Local Self-Government 7 (3): 243-256.

Sloan, L. 2011. Measuring minor parties in English local government: Presence vs. vote share. Local Politics Specialist Group. Accessed May 5, 2015. http://www.psa.ac.uk/2011/Uploaded PaperPDFs /719_270.pdf. 
Sotiropoulos, E. 2008. A reformed Senate as a check on prime ministerial power. $\mathrm{Ca}$ nadian Parliamentary Review 31(1): 2833.

Stalebrink, O. J. 2007. An investigation of discretionary accruals and surplus-deficit management: Evidence from Swedish municipalities. Financial Accountability and Management 23 (4): 441-458.

Tagesson, T. 2008. Accrual accounting does not necessarily mean accrual accounting: Factors that counteract compliance with accounting standards in Swedish municipality accounting. Scandinavian Journal of Management 24 (3): 271-283.

Taylor, D.W., and M. Rosair. 2000. The effect of participating parties, the public and size on government departments' accountability disclosures in annual reports. Accounting, Accountability and Performance 6 (2): 77-98.

Tolbert, P. S., and L. G. Zucker. 1983. Institutional sources of change in the formal structure of organizations: The diffusion of civil service reform. Administrative Science Quarterly 28 (1): 22-39.

Undang-undang Republik Indonesia No.22 tahun 1999, Pemerintah Daerah, Retrieved: 3 May 2011, from http://www.esdm.go.id/.../uu/.../270undang-undang-no22-tahun-1999.html.
Undang-undang Republik Indonesia No. 27 tahun 2009, Majelis Permusyawaratan Rakyat, Dewan Perwakilan Rakyat, Dewan Perwakilan Daerah, dan Dewan Perwakilan Rakyat Daerah, Retrieved: 3 May 2011, from: http://www.id.wikisource.org/ wiki/UndangUndang_RepublikIndonesia Nomor_27_Tahun_2009.

Usman S. 2001. Indonesia's decentralization policy, initial experiences and emerging problems. This paper was prepared in The Third EUROSEAS Conference Panel on Decentralization and Democratization in Southeast Asia, London, September 2001.

Velleman P. F., and R. E. Welsch. 1981. Efficient Computing of Regression Diagnostics. The American Statistician 35 (4): 234-242.

Ying, Z. I., and L. Zhengfei 2006. The relationship between disclosure quality and cost of equity capital of listed companies in China. Economic Research Journal 2 (7): 2-17.

Yoshikawa, T., L. S. Tsui, dan J. McGuire. 2007. Corporate governance reform as institutional innovation: The Case of Japan. Organization Science 18 (6): 973988.

\footnotetext{
${ }^{1}$ The territory of Indonesia is divided into autonomous provinces, districts (kabupaten) and municipalities (kota). Districts and municipalities are technically the same level of government. This distinction is based on whether the government administration is located in a rural area (district) or an urban area (municipality). Within districts and municipalities there are sub-districts (kecamatan) which are smaller administrative government units. Each sub-district is further divided into villages. Villages in rural areas are called desa, while in an urban areas there are referred to as kelurahan (Usman, 2001). This study focuses on the district and municipality levels that are referred to in this study as 'local government'.

${ }^{2}$ Under Act No. 27 of 2009, In Indonesia, there are three levels of parliament; those are state parliament, provincial parliament, and local parliament. This study focuses on the local parliament level consisting of districts and municipalities members.
} 
${ }^{3}$ A method of sampling that involves the division of a population into smaller groups known as strata. In stratified random sampling, the strata are formed based on members' shared attributes or characteristics. A random sample from each stratum is taken in a number proportional to the stratum's size when compared to the population. These subsets of the strata are then pooled to form a type of random sample. In this study, the division of strata includes districtmunicipality, old-new age of local government, surplus-loss of local government, and Java and non-Java.

${ }^{4}$ Financial independence is measured by the ratio of local government financial independence (RLGFI). According to Alicias et al. (2007) the local financial formula is local government revenue divided by local government revenue plus revenue from state and province entities.

${ }^{5}$ Classical assumptions of multiple regressions (multicollinearity, normality, linearity, outliers, and homoscedasticity) have been checked with the conclusion that all of the assumptions were met (see Hair, Anderson, Tatham, and Black 1988). Multiple regression analyses can be severely and adversely affected by failures of the data to remain constant with the assumptions that customarily accompany regression models. Mahalanobis distance and Cook's distance as diagnostic methods are available to help identify certain kinds of failure as outlier data. Diagnostics are thus valuable adjuncts to regression analyses. Mahalanobis distance and Cook's distance are capable of producing partial plots in the SPSS program. This allows for the saving of residuals (Velleman and Welsch 1981). From the residual, Mahalanobis value should be $<26.52$ (based on seven predictor variables), and Cooks value should be $<1$ (Cook and Hawkins 1990). The analysis shows no concerns with outlier values. The results of this regression are summarized in Table 6. 